\title{
The Modernization of Routes
} and New Railway Lines: Different Viewpoints and Instruments
for Commercial Objective

\author{
Andrés López-Pita and Francesc Robusté
}

Center for Transportation Innovation, Technical University of Catalonia

\section{$\overline{\text { Abstract }}$}

This article presents the concept of "objective travel time" as a key variable in railway line modernization decision making. The concept tries to achieve a threefold goal: optimization of economic resources, significant presence of the railway in the market share of the corridor, and a positive operational balance. The concept has been successfully applied in the new Rail Investment Program in Spain.

\section{Introduction}

The desire to improve the quality of intercity railway passenger services by reducing journey times has always existed. In the 1950s, this desire became an indispensable necessity in Europe for two reasons: (1) the rapid development of new road infrastructures (e.g., dual carriageways and motorways) and (2) the increasingly widespread use of the airplane for middle- and long-distance journeys within Europe. This increase in the use of air transport services was due to the introduction of the reactor, which provided greater speed, safety, and comfort.

In an initial phase (1960-1975), some European countries, especially France and the United Kingdom, carried out important modernizations on their 
principal lines to achieve higher running speeds and, as a result, shorter journey times.

After having exhausted the possibilities of modernizing the routes constructed in the 19th century, each country took a different approach:

- France opted for the construction of new railway infrastructures, suitable for running speeds of $300 \mathrm{~km} / \mathrm{h}$.

- The United Kingdom chose to put its faith in the technology of the vehicles whose bodies tilt when negotiating curves.

The technical, commercial, and economic success achieved by the French railways with the operation of the new high-speed line between Paris and Lyon immediately gave rise to the construction of new high-speed lines in France: TGV-Atlantic and TGV North. Soon after in 1991, the French government approved the Guidelines for New Railway Lines, which basically involved constructing a new, 4,700, km-long high-speed line.

Meanwhile, British Rail was unable to perfect its tilting-body train, called APT, and eventually abandoned this approach in 1986. Interestingly, two years later, in 1988, the Italian railway company put a tilting-body train (the ETR 450 ) into commercial service. In 1980, Spain's Talgo Pendular train had entered into commercial service.

In short, the major European railway companies adopted two different approaches: on the one hand, the construction of new lines that allow trains to run at high speeds and, on the other, the use of trains with tilting bodies.

The construction of new railway infrastructures requires significant financial resources, which are increasingly substantial due to the need to take greater precautions for protecting the environment. For example, the cost per $\mathrm{km}$ of the first high-speed line in France (between Paris and Lyon) was a third of the cost per $\mathrm{km}$ of the new line between Valence and Marseilles, which entered into commercial service in June 2001.

In Europe, this situation has recently given rise to an extensive debate about the relative merits of investing in the use of rolling stock with tilting bod- 
ies as opposed to the construction of new lines, given the lower financial cost that this represents.

In this context, this article offers an in-depth analysis of this problem and, at the same time, explains the methodology proposed to decide which investment is most advisable for any given service. This methodology was used by the Spanish government during 1999.

\section{The Need for New Railway Infrastructures in Europe: An Objective Fact?}

The first efforts to improve the quality of intercity railway passenger services in Europe focused on the maximum exploitation of the possibilities offered by the existing routes. However, we should not forget that the Japanese national railway company's decision at the end of the 1950 s to construct a new line for the development of high speed between Tokyo and Osaka marked the beginning of a duality that still exists today: constructing new infrastructures or modernizing those already in existence.

It is useful to recall what Louis Armand, the former president of the International Union of Railways (UIC), stated in 1967:

The future of railway passenger transport cannot be imagined without the development of high speed. The main approaches to be taken in this field can be divided into two categories: the modernization of what already exists, should we wish to surpass a certain level of speed (approximately $160 \mathrm{~km} / \mathrm{h}$ ), or the construction of new lines, as the Japanese have already done with the new Tokaido. The problem is, therefore, deciding whether we want to invest in order to perfect or in order to create.

The process undergone in certain European countries from the 1960s to the present day can teach us a number of lessons that relativize theoretical dogmas and provide interesting approaches for guiding the investment decision required of each railway line.

In this context, the construction of the first high-speed infrastructure in France was, in our opinion, essentially based on three facts: 
1) The worrying evolution of the French railway company's share of the market on the Paris-Lyon route, as shown in Tablel. Despite the fact that the railway offered a journey time of four hours (commercial speed of $128 \mathrm{~km} / \mathrm{h}$ ), as opposed to three hours by airplane and five hours by private vehicle (from the center of Paris to the center of Lyon), the railway lost 17 percent of the share of the market in four years (1963 to 1967), a loss which, in accordance with the forecasts, was to have increased by a further 23 percent only nine years later.

2) Problems relating to a lack of capacity that the Paris-Lyon line suffered in the early 1970 s, with over 260 journeys on certain days.

3) Verification from 1972 onwards of the continuing fall in the number of first-class passengers using intercity services from Paris (Figure 1). At that time, Paris was linked to 143 French towns and cities at more than $100 \mathrm{~km} / \mathrm{h}$ in terms of commercial speed, with 67 towns and cities at 120 $\mathrm{km} / \mathrm{h}$, and with 6 cities at more than $140 \mathrm{~km} / \mathrm{h}$.

Table 1

Modal Distribution of Passenger Traffic on the Paris-Lyon Route (1963-1976)

\begin{tabular}{|c|c|c|c|}
\hline Mode of Transport & 1963 & 1967 & $\begin{array}{c}\text { Forecast for } \\
1976\end{array}$ \\
\hline Railway & $65 \%$ & $48 \%$ & $25 \%$ \\
Airplane & $7 \%$ & $20 \%$ & $39 \%$ \\
Road & $28 \%$ & $32 \%$ & $36 \%$ \\
\hline
\end{tabular}

Source: Walrave (1970).

With respect to the approach taken by the United Kingdom to improve the quality of its railway passenger transportation services, the decision was, in our opinion, basically due to these facts:

1) The satisfactory position of British Rail in terms of market share on the routes situated within a radius of approximately $400 \mathrm{~km}$ from London (Table 2). 


\begin{tabular}{|l|c|c|c|}
\hline \multicolumn{4}{|c|}{$\begin{array}{c}\text { Table } 2 \\
\text { Modal Distribution of Passenger Traffic on Certain Routes } \\
(1980)\end{array}$} \\
\hline \multirow{3}{*}{ From London to } & Road & Airplane & Railway \\
\hline Manchester (300 km) & 42 & 27 & 31 \\
Newcastle (430 km) & 20 & 35 & 45 \\
Leeds (288 km) & 48 & 9 & 43 \\
\hline
\end{tabular}

Source: Button (1993).

2) The introduction of commercial services with tilting-body vehicles which, due to the nature of certain sections of the routes, could reach speeds of $250 \mathrm{~km} / \mathrm{h}$ would significantly reduce the journey times (Table 3). Consequently, it was estimated that between London and the three cities mentioned in Table 3, the railway would have a market share of 80 percent, as opposed to the 20 percent corresponding to the airplane.

3) The construction of a new high-speed line heading north out of London would only significantly benefit the most distant population centers: Glasgow and Edinburgh $(650 \mathrm{~km})$. With the tilting-body vehicles it would be feasible to link both cities in four hours, giving the railway an estimated market share of between 50 and 60 percent with respect to the airplane.

Subsequently, we must ask whether the respective approaches of each country were right.

\begin{tabular}{|c|c|c|}
\hline \multicolumn{3}{|c|}{$\begin{array}{l}\text { Table } 3 \\
\text { Foreseeable Effect of Tilting Trains on Journey Times on Certain } \\
\text { Routes } \\
\end{array}$} \\
\hline \multirow[b]{2}{*}{ From London to } & \multicolumn{2}{|c|}{ Journey Time } \\
\hline & $\ln 1980$ & With Tilting Trains \\
\hline $\begin{array}{l}\text { Manchester } \\
\text { Newcastle } \\
\text { Leeds }\end{array}$ & $\begin{array}{l}2 \mathrm{~h} 25 \\
3 \mathrm{~h} \\
2 \mathrm{~h} 07\end{array}$ & $\begin{array}{l}2 \mathrm{~h} \\
2 \mathrm{~h} 20 \\
1 \mathrm{~h} 45\end{array}$ \\
\hline
\end{tabular}

Source: Authors. 


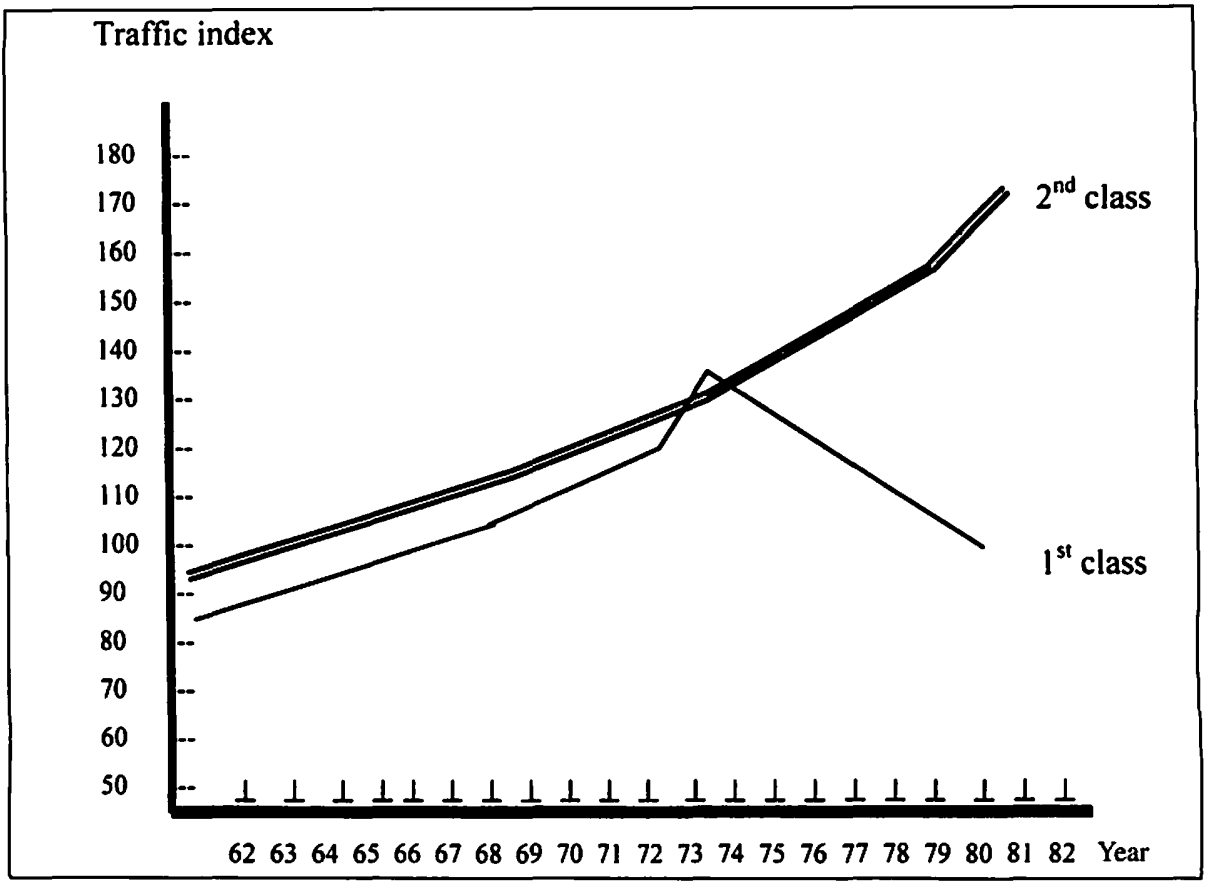

Source: Mireaux (1985).

Figure 1. The evolution of long-distance passenger traffic in SNCF 1962-1982

As for the French, the existing experience with the evolution of railway passenger traffic on intercity routes not served by high-speed lines confirms that the right decision was made (Table 4).

In fact, on routes offering high-speed services, traffic increased by 45 percent between 1990 and 1995, whereas on the routes without this type of service, traffic fell by 18 percent. These trends are still evident today.

In regards to the English decision, it was impossible to perfect the tiltingbody vehicle, leading to the project being abandoned in 1986 (Figure 2).

The commercial use of vehicles with tilting bodies, as proposed by British Rail, required a 20- to 30-year research period. This technology was not actually available when the construction of the high-speed line between Paris and Lyon began (Figure 2).

At the moment, tilting-body technology has reached a satisfactory level of development. This type of rolling stock will enter into service on the 
Table 4

Evolution of Long-Distance Passenger Traffic on French Railways (1990-1995)

\begin{tabular}{|c|c|c|}
\hline \multirow{2}{*}{ Year } & \multicolumn{2}{|c|}{ Rate of Evolution of Traffic on } \\
\cline { 2 - 3 } & Lines with TGV Services & $\begin{array}{c}\text { Lines without High- } \\
\text { Speed Services }\end{array}$ \\
\hline 1990 & 100 & 100 \\
\hline
\end{tabular}

Source: Authors.

London-Glasgow and London-Edinburgh lines in 2003/2004, once the respective layouts have been suitably modernized.

Whatever the case, we do not believe that false comparisons should be made between new infrastructures and tilting-body vehicles. Both possibilities are useful instruments at the railway's disposal for providing the most suitable commercial, technical, and financial response to the needs of the demand on any given route.

Table 5 shows how an approach based on modernization of lines, pendulation, tilting, or construction of new infrastructures has enabled the railway to secure very significant market shares. This reality confirms the value of each of these actions.

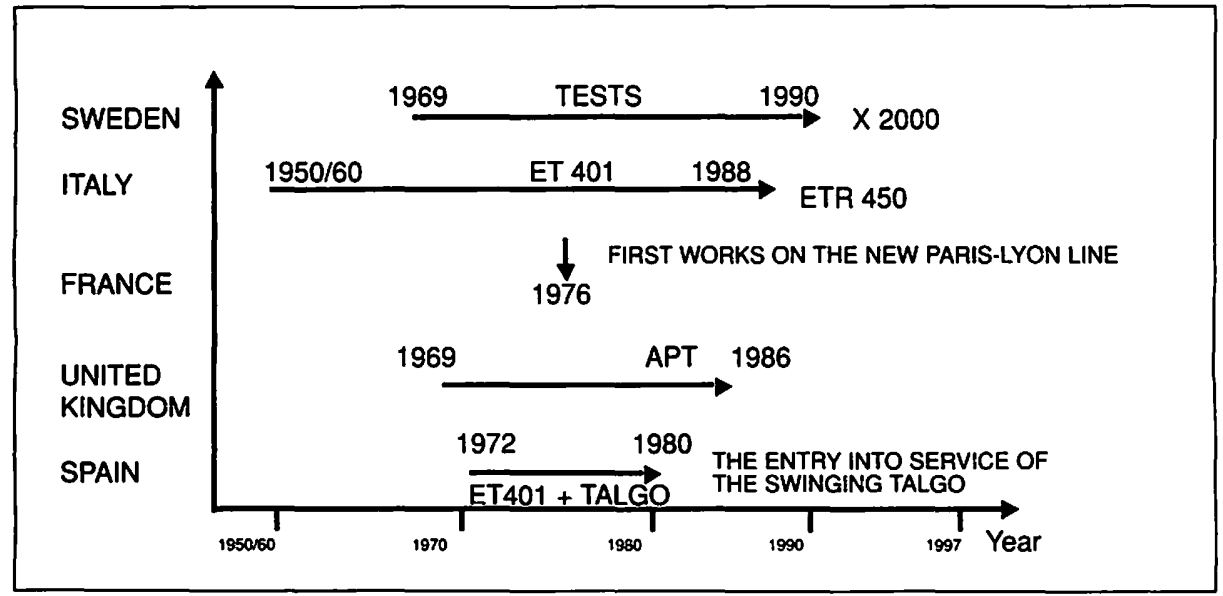

Source: López-Pita (1999).

Figure 2. Historical development of tilting-body systems 


\begin{tabular}{|c|c|c|c|c|c|}
\hline \multirow{4}{*}{ Country } & \multicolumn{5}{|c|}{$\begin{array}{c}\text { Table } 5 \\
\text { The Technology Used and Railway Market Share }\end{array}$} \\
\hline & \multirow[b]{3}{*}{ Service } & \multirow[b]{3}{*}{ Line } & \multirow{3}{*}{$\begin{array}{l}\text { Journey } \\
\text { Time }\end{array}$} & \multicolumn{2}{|c|}{ Market Share } \\
\hline & & & & Rail & Rail \\
\hline & & & & All Modes & Air \\
\hline Germany & $\begin{array}{l}\text { Hamburg-Frankfurt } \\
\text { Frankfurt-Munich }\end{array}$ & New + Modernized & 3h 40 & $39 \%$ & $44 \%$ \\
\hline & & New + Modernized & $3 \mathrm{~h} 30$ & $37 \%$ & $53 \%$ \\
\hline Sweden & Stockholm-Gothenbourg & $\begin{array}{l}\text { New }+ \text { Modernized }+ \\
\text { Rocking }\end{array}$ & $2 \mathrm{~h} 59$ & $\cdots$ & $55 \%$ \\
\hline Spain & $\begin{array}{l}\text { Madrid-Seville } \\
\text { Madrid-Malaga }\end{array}$ & $\begin{array}{c}\text { New } \\
\text { New + Swinging }\end{array}$ & $\begin{array}{c}2 \mathrm{~h} 15 \\
4 \mathrm{~h}\end{array}$ & $48 \%$ & $\begin{array}{l}82 \% \\
30 \%\end{array}$ \\
\hline France & $\begin{array}{l}\text { Paris-Lyon } \\
\text { Paris-C. Ferrand } \\
\text { Paris-Strasbourg } \\
\text { Paris-Montpellier }\end{array}$ & $\begin{array}{c}\text { New } \\
\text { Modernized } \\
\text { Modernized } \\
\text { New + Modernized }\end{array}$ & $\begin{array}{c}2 \mathrm{~h} \\
3 \mathrm{~h} 19 \\
4 \mathrm{~h} \\
4 \mathrm{~h} 15\end{array}$ & $\begin{array}{c}40 \% \\
35 \% \\
\ldots \\
-\ldots\end{array}$ & $\begin{array}{l}90 \% \\
80 \% \\
44 \% \\
49 \%\end{array}$ \\
\hline
\end{tabular}

Source: López-Pita (1999).

\section{A New Methodology for Making Decisions}

Practical experience shows that journey time plays an essential role in the customer's choice of transport mode. The methodology proposed below is based on the idea of defining journey time ("objective").

Specifically, this methodology involves determining the quality of the service (with respect to journey time), which, by optimizing financial resources, represents a significant presence of the railway in the transport system of any given corridor, and determines a positive operating balance for the operator of the line. That is, it is not a matter of traveling as fast as is technically possible, but as fast as commercially and financially necessary. Two examples are presented here to illustrate this point.

Consider, by way of example, the possible influence of the reduction of the current journey time by rail (two hours) between Paris and Lyon. What 
would be the foreseeable effect of an investment aimed at achieving a journey time of, say, $1 \mathrm{~h} 45 \mathrm{~m}$ ?

The application of demand modeling techniques and the evaluation of income and operating costs associated with a certain kind of traffic allow us to obtain a response for that specific route. From the point of view of securing extra demand, all of which would come from air traffic, the railway's current 90 percent share of the market would rise to 95 percent. With regard to this existing relationship with air traffic, the vast majority of new customers are captured from air traffic due to connections and reasons of proximity to their place of residence or work.

From the point of view of operating costs, the market share would increase significantly. This would be due to the need to raise the maximum speed from $260 / 270 \mathrm{~km} / \mathrm{h}$ to $300 \mathrm{~km} / \mathrm{h}$, with the consequent increase in energy consumption that this would entail.

The overall economic balance is negative. It cannot be said that an investment decision, which, with respect to the route in question aimed to reduce the existing journey time by rail, would be commercially and financially justified (and without taking into account the possible supplementary investments in the railway line and in the rolling stock). We call this phenomenon "the price of excess speed."

The second example corresponds to the opposite situation: insufficient commercial performances. Consider the case of the Madrid-Barcelona route in Spain. At one stage the possibility of constructing two variants along the length of this route was considered a way of reducing the journey time by rail. The investment required for constructing these variants exceeded $\$ 1$ billion and the journey time would fall from $6 \mathrm{~h} 30 \mathrm{~m}$ to approximately $5 \mathrm{~h} 30 \mathrm{~m}$.

Once again, the application of demand modeling techniques allows us to quantify this effect. The expected result for the capture of new demand was relatively insignificant.

This conclusion should be analyzed in light of the fact that there are 62 flights a day in each direction between Madrid and Barcelona, with fares similar to those of the railway at certain times of the day.

The two preceding illustrative examples lead to the following reflections: 
1) On occasion, reducing the journey time by rail below a certain level may imply an unsuitable and unnecessary investment (first example).

2) On occasion, investing to reduce the journey time by rail, but keeping this time above a certain level, may imply an investment that is of little interest to the railway (second example).

Based on the above reflections, it is advisable for each railway route under consideration to establish the journey time ("objective"). This will depend on, among other variables, the transport market conditions corresponding to the route in question.

Figure 3 shows that for railway to achieve market shares, with respect to other transport modes, of around 48 percent, it is not necessary to achieve the same journey time over the same distance, or a similar commercial speed. For a lower market share level $(\sim 40 \%)$, a French example and a German example illustrate the same point.

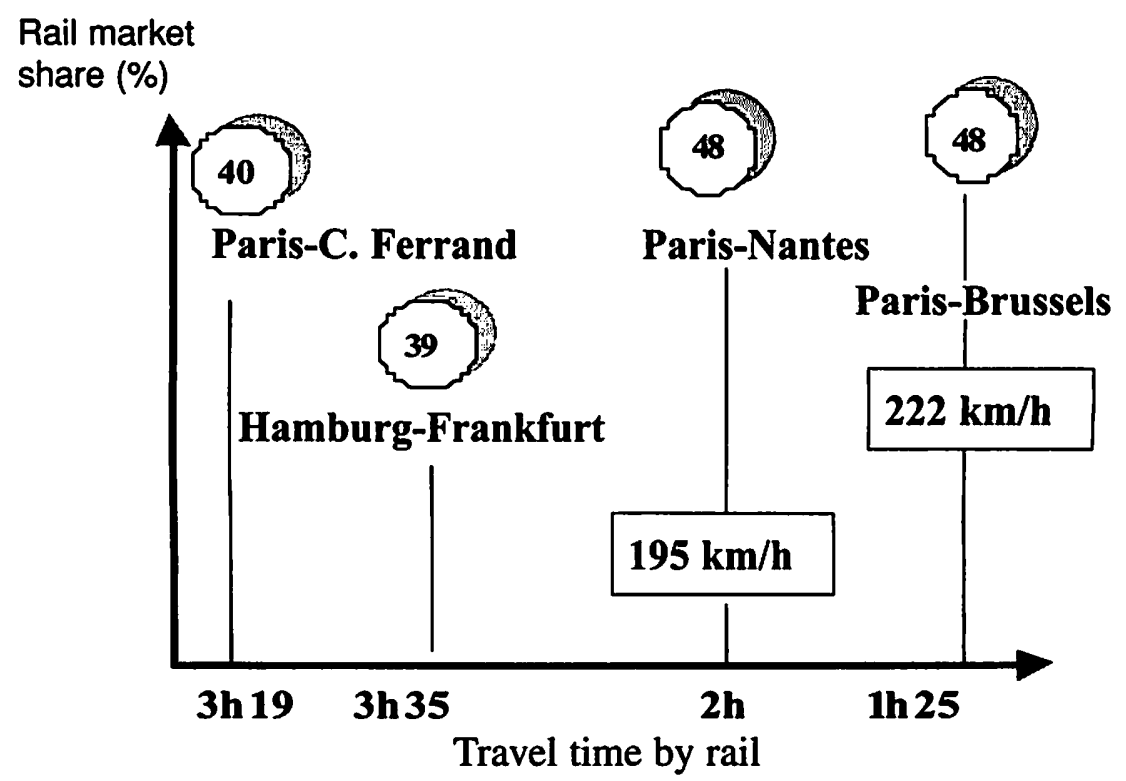

Source: López-Pita (2000).

Figure 3. "Objective travel time" in some European relationships 
Each route considered here is a singular case and requires specific analysis.

In summary, the goal is to establish an investment policy that will make it possible to increase rail transport, and at the same time generate a growth in economic activity on the corridor concerned.

\section{Application to the Spanish Case}

The Spanish railway carries out its activity within the framework of a transport system in which the two principal modes, air transport and road transport, have reached levels of quality and development that are unlikely to undergo major modifications. In this context, it is important to address the role of the Spanish railway in the 21st century within the sphere of intercity passenger services.

For this purpose, a series of studies was carried out in relation to the main corridors, basically radial routes linking Madrid with the rest of Spain's provincial capitals. The objective was to specify the practical significance of the "attractive railway offer" concept. This concept encompassed three aspects:

1) The need to optimize the financial resources allocated to railway investments, especially at a time when European governments are attempting to achieve a zero public deficit.

2) The suitability of achieving a significant presence of the railway, in terms of market share, to reduce the excessive demand that burdens other modes of transport.

3) The need to achieve a positive economic balance in the operation of the lines.

From a practical point of view, the methodological process consisted of analyzing, for each route considered, the effect of reducing the existing journey time by rail. In general, two or three inferior times were considered and their effect was quantified in terms of:

- investment required,

- traffic the railway could capture,

- the railway's share of the market, and

- economic balance for the operator, including the possible need to acquire new rolling stock. 
The use of certain complementary indicators, such as the investment relating to the increase in traffic or the additional investment for achieving a certain additional increase in traffic, made it possible to immediately choose the most advisable investment alternative and, therefore, the objective journey time associated with it. Figure 4 shows the results obtained. The construction projects necessary for implementing the scheduled investments are currently in the process of being drawn up.

\section{Conclusions}

This article has highlighted the fact that investment in the railway aimed at improving the quality of intercity passenger services cannot be based on apriorisms about the type of action: construction of new lines or utilization of tilting-body vehicles.

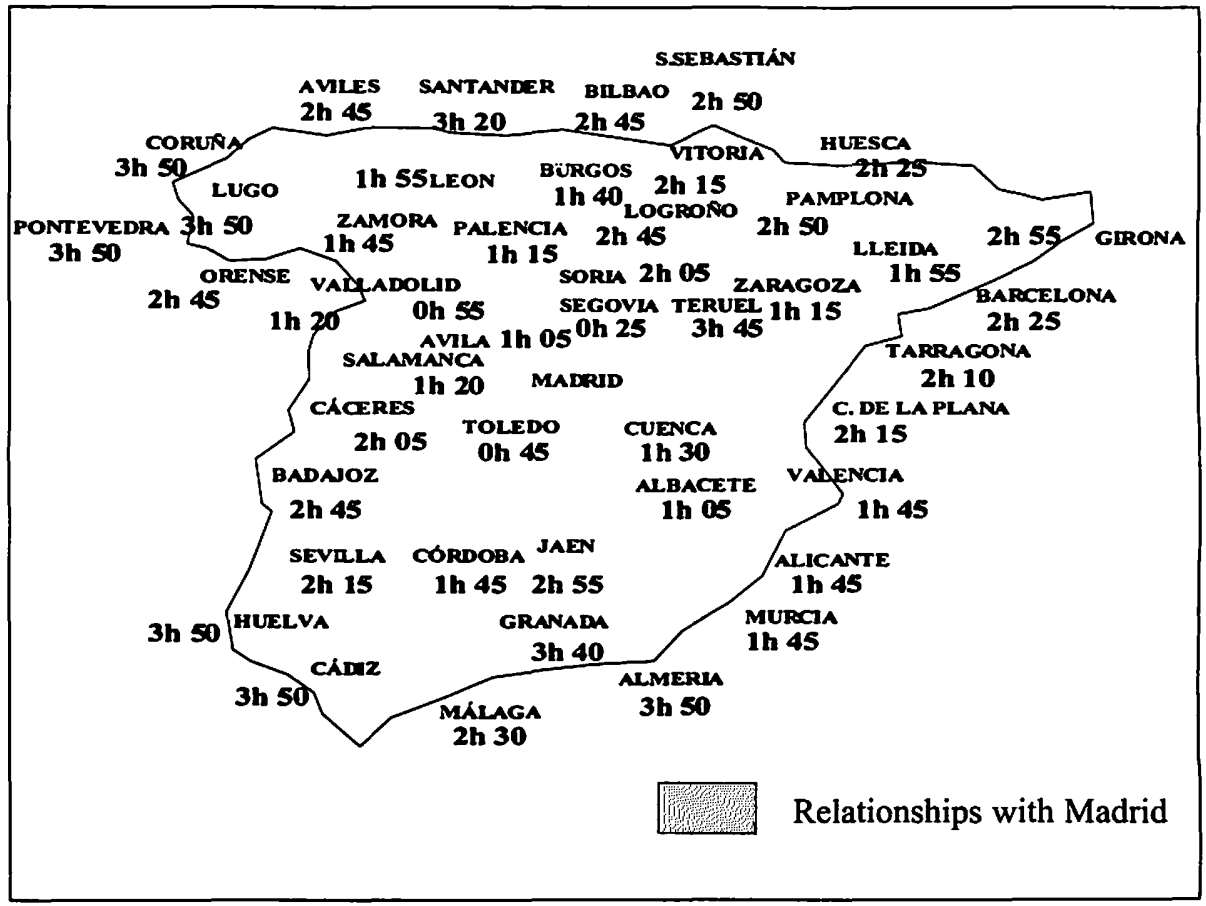

Source: Ministerio de Fomento (2000).

Figure 4. Investment program in railway infrastructures 2000-2007 objective travel lines 
With regard to each country and each route considered, it is necessary to carry out an analysis that determines the most suitable course of action from the commercial and financial points of view.

The Spanish railway has adopted a methodology based on finding the "objective time" of each route (i.e., the service quality that optimizes financial resources and performances).

The evaluation of the "objective time" is the end result of a process that considers a series of journey times by rail that are inferior to the existing time, and selecting them by comparison with those offered by road or air transport.

This methodology has been applied to the Spanish railway and has made it possible to avoid approaches based on radical, generally willful hypotheses, or approaches based on hypotheses that have an insufficient effect on the improvement of the rail service.

\section{References}

Button, K. 1993. High speed rail transport. Its role in the U.K. The third International

Conference on Economics of Innovation. The case of the high speed rail, Piacenza, Italy.

López-Pita, A. 1999. Tilting trains and line construction. Ministerio de Fomento.

López-Pita, A. 2000. El tiempo óptimo de viaje y las decisiones de actuación en un corredor ferroviario. IV Congreso de Ingenieria del Transporte, Valencia, Spain, 4: 2103-21011.

Mireaux, J. 1985. Le projet de nouvelle lere clase. Revue Générale des Chemins de Fe, October: $35-42$.

Walrave, M. 1970. L'analyse de la demande. Revue Générale des Chemins de Fer March: 70-80.

\section{About the Authors}

ANDRÉs LóPEZ-PITA (andres.lopez-pita@upc.es) is a lecturer in railway engineering and director of the Center for Transportation Innovation at the Technical University of Catalonia. He has several years of research experience in transportation planning. He has been a member of the board of directors of Spanish railways. 
FranCESC RobusTÉ (f.robuste@upc.es) received his Ph.D. in engineering at the Technical University of Catalonia at Barcelona, and a master of science in operations research and master of engineering in transportation at the University of California at Berkeley. He is an associate professor of transportation and academic secretary of the Civil Engineering School at Barcelona. Dr. Robusté is the author of 146 publications and a member of the editorial board of Transportation Research (1992-2000). 